\title{
1. The transformation of the European Economic Constitution
}

\author{
Herwig C.H. Hofmann and Katerina \\ Pantazatou
}

This chapter reviews shifting approaches to what we refer to in this book as the 'European Economic Constitution'. It argues that we are witnessing a shift in models towards the European Economic Constitution and argues that the model necessary is to move the understanding of the European rules as neutral towards economic and ideological approaches, allowing it to develop a legal framework that fits within an encompassing model of an EU Economic Constitution integrated into the overall constitutional framework.

In order to do so, this chapter focuses inter alia on the way today's Economic and Monetary Union (EMU) has med a model of economic government and economic governance tools tina are used in parallel to deepen integration and enhance its spillover effects into previously national policies.

While the causes of the various economic, financial and regulatory of the decade starting with the entry into force of the Treaty of List in December 2009 are multifaceted and often subject to debate as to their reasons and significance, it is widely accepted that the recent crisis showed that the EU Constitution in its existing form did not provide an adequate legal framework to cope with all the new (crisis-induced) challenges. ${ }^{1}$ This failure has, in our view, initiated an ongoing transformation of the EU Economic Constitution as we know it. Already the creation of the EMU had added to the original, Treaty provisions primarily aimed at the 'microeconomic' model addressing matters such as State aid, competition law and the fundamental freedoms.

However, the constitutional framework in place since the Treaty of Lisbon has furthered the need for transformations linking elements of the constitu-

1 Although we believe that the Union, since its earliest days has been continuously plagued by different types of crises - political, social and legitimacy - we also believe that it has been the crises and the creative thinking necessary to overcome them which has led to the dynamic nature of EU law as we know it. However, in this paper we refer mostly to the economic, financial and state recourse-related crisis that hit the EU in 2008 with all the multiple repercussions that this crisis brought about in other areas. 
tional structure. Not only did the Treaty of Maastricht add the EMU, but also the often 'crisis-induced' developments of the past decade have given rise to a vast expansion of new tools dealing with macroeconomic approaches to state financing, price stabilities and public deficits, ruling on traditionally national competencies such as social and labour law and fiscal policies. Also, developments in the area of the EU fundamental rights have influenced the microeconomic elements of the Economic Constitution.

\subsection{THE EVOLUTION OF THE EU ECONOMIC CONSTITUTION}

The conceptual underpinnings of an economic constitution raise essential questions for the understanding of the EU. Understanding the notion of the eonstitutionalization of the Eeonomie Constitution's approach requires looking at phases of development within the integration process.

\subsubsection{Early Concepts of a European Economic Constitution}

The original regulatory framework of economic activities through the EEC Treaty was based on ensuring market-related values of competition and market freedoms. It did not necessarily require these values and freedoms to be embedded within a broader concept of societal values. ${ }^{2}$

Constitutionalization of the Treaties in the context of establishing European law as an autonomous legal order was, at the time at least in part, related to the concept of a specific policy area - that of economic integration. Under the EEC Treaty, economic integration was singled out and used as a stepping stone for further integration in other fields.

The original thinking behind seeing the EEC in line with a functionalist tradition has been described by contemporaries as a 'special purpose vehicle' under public law - the Zweckverband theory of the early days of integration. ${ }^{3}$ The approach of describing the Communities as 'special purpose vehicles'

2 Francesco de Cecco, State Aid and the European Economic Constitution (Hart Publishing 2013) 17; Christian Joerges and Maria Weimer, 'A Crisis of Executive Managerialism in the EU: No Alternative?' in Grainne de Búrca, Claire Kilpatrick and Joan Scott, Critical Legal Persepectives on Global Governance (Hart Publishing 2014) 295.

3 Hans-Peter Ipsen, 'Der deutsche Jurist und das Europäische Gemeinschaftsrecht', 43 Deutscher Juristentag 1964, Vol. II, L 14; Hans-Peter Ipsen, Europäisches Gemeinschaftsrecht (Mohr 1972), 196. Therein he outlines his theory of the EU being a third structure between national public law and public international law with the communities as 'Zweckverband funktioneller Integration', being specific structures under public law for achieving technocratic purposes. 
understood integration as a distinctively technocratic approach to regulating matters of economic policy relevant for the creation of a single market and a shared legal regulatory space.

In the context of this early approach, one of the cornerstones of the =f conomic Constitution- were the economic freedoms of the EEC Treaty - the free movement of goods, services, workers, establishment and (later) capital. Another essential counterpart to the freedoms consisted of the Treaty provisions establishing a system of competition law rules including the control of state aids of the Member States. ${ }^{4}$ The core of the Constitution- was thus at the time understood to consist of a supranational regulatory framework for the legal integration of the formerly separate markets. The possibilities for 'harmonising' or approximating the regulatory framework across the single market was already initially present but significantly developed in the Single European Act and later Treaty admendments. Interestingly, under some early proponents of the 'Zweckverband' approach, the exercise of such powers did not depend upon original European-based democratic credentials, ${ }^{5}$ although later Treaty amendments sought continuously to expand the powers of the European Parliament in order to enhance parts of such genuine legitimation.

The early conception of an Economic Constitution of market regulation and empowerment of individuals was designed in view of ordoliberal concepts of market regulation and the relation between public and private actors. The economic constitution as a 'general political decision as to how the economic life of the nation is to be structured ${ }^{6}$ was accordingly initially predominantly inspired by the need for 'economic rationality' allowing for economic freedoms in a strong regulatory framework. The construction of an Economic Constitution (both at national and supranational level) required 'strong' regulatory powers to allow or enable the enforcement of conditions of a 'free market' and to protect individual freedor $=\mathrm{m}$ abuses of both private and public economic power. ${ }^{7}$ Thus, in the Europual context, the focus on a system of undistorted competition encompassed not only the control of economic

4 Christian Jörges, 'Europe's Economic Constitution in Crisis and the Emergence of a New constitutional Constellation', Zentra Working Paper in Transnational Studies No. 06/2012 (revised in September 2013), p. 3.

$5 \quad$ Hans-Peter Ipsen, Europäisches Gemeinschaftsrecht (Mohr 1972), 196.

$6 \quad$ Franz Böhm, Walter Eucken and Hans Grossmann-Doerth 'The Ordo Manifesto of 1936' in Alan T. Peacock and Hans Willgerodt (eds), Germany's Social Market Economy: Origins and Evolution (Macmillan 1989), 15-26.

7 David J. Gerber, 'Constitutionalising the Economy: German Neo-Liberalism, Competition law and the 'New' Europe' (1994) 42 American Journal of Competition Law 25. 
power and monopolies but also potentially anticompetitive state activities and regulatory practices. ${ }^{8}$ European law, in the words of the original Article 3 (f) EEC (Treaty of Rome 1957), was designed for 'ensuring that competition shall not be distorted in the Common Market'. However, some heavy market interventions were possible in the context of certain policy areas such as agriculture and fisheries. ${ }^{9}$

\subsubsection{Developing Models of Constitutionalization}

This early approach to $\underline{\underline{E}}$ institutionalization- differs considerably from later phases of constitutivinaization, which led to the transformation of the Economic Constitution in both widening and deepening of the integration process.

The increasing exercise of competencies by the European institutions brought about challenges to the legitimacy of the European legal order, which had already established the principles of supremacy and direct effect in the context of a specific regulatory framework for economic law and policy. Next to political challenges as to the locus of power (residing with the Member States or with supranational institutions),${ }^{10}$ the first set of legal challenges were those of whether the European $E$ onomic Constitution- could overrule fundamental rights protection establisicd within Member State constitutions, testing the limits of the 'economic' part of the Constitution.

With case law subsequent to Stauder (1969) establishing that 'the fundamental human rights' are 'enshrined in the general principles of Community law' and are 'protected by the Court', 1 the Court of Justice began to address this resistance. Other responses consisted of attempts to transform the originally technocratic approach involving largely the executive branches of power into a more accountable systen $\underline{\underline{\underline{I I}}}$ re compatible with the conceptions of the legitimate exercise of public pu...ers. Accordingly, the strengthening

8 Christian Jörges, 'The European Economic Constitution and its Transformation through the Financial Crisis' in Dennis Patterson and Anna Söderstn (eds), A Companion to EU Law and International Law (Wiley-Blackwell 2015) 242.

9 See e.g. Joseph A. McMahon, 'The Common Agricultural Policy' in Herwig C.H. Hofmann, Gerard C. Rowe and Alexander H. Türk (eds), Specialized Administrative Law of the European Union (OUP 2018) 511, who points out also the evolutions of the CAP, despite, unlike the area of the European Economic Constitution, the Treaty provisions regarding agriculture having essentially remained unchanged since the Treaty of Rome.

10 See for example the so called 'empty chair policy' of the late period of Charles de Gaulle as French president who sought to defend, inter alia, national vetoes by perpetuating the requirements of unanimity in Council votes.

11 Case 26/69 Stauder EU:C:1969:57 [1969] ECR 419. 
of the genuine European credentials of EU institutions is exemplified in the development of the European Parliament (EP), which since 1979 has been directly elected and has since the Single European Act has steadily gained power thards a - legislature. Also, the European Commission has gained independence wi e President of the European Commission in 2014 for the first time having been elected explicitly reflecting the majorities in the EP.

In the wake of this, the entire spectrum of policies now touched by integration has been submitted to general constitutional concepts anc Eu ropean values listed in Article 2 TEU and the Charter of Fundamental Rignits of the Union including compliance with fundamental rights, democracy, transparency, the rule of law and good administration. It is, however, not clear how these fundamental values are translated into policy areas where the move towards democratic rule-making in genuinely European approaches is ensured since the expansion of the ordinary legislative procedure in Article 294 TFEU as a default procedure for legislation in nearly all policy areas of the TFEU but for the EMU.

The overall approach has been both a broadening and a deepening of integration, for example under the Treaties of Maastricht and Lisbon. The former sought to broaden economic law from a competition and economic freedom-based approach to include a more encompassing Monetary Union. The latter heavily contributed to constitutionalization by (re-)embedding economic law into one, European, constitutional framework in the form of the Treaties lato sensu.

\subsubsection{Changing Modes of the European Economic Constitution?}

Irrespective of these truly constitutional developments, there is, however, the question whether the basic understanding of an undistorted market and a system of competition control has changed. These policies were the generator of the EU construction and the motor of economic integration. They were the origin of much of what has been described by (neo-)functional theory as spillover both in terms of further 'integration by regulation' but also in terms of institutional development.

Nevertheless, the idea of spillover needs qualification in institutional terms. This can be described by the metaphor of European integration generally following a model of concentric circles. The process of European integration of a policy field is generally introduced through inter-governmental cooperation. Depending on the policy area, this can be followed by 'communitarization' when unanimity is ensured at the Council, or it can be submitted to the full rigour of the 'Union method' with (qualified) majority voting in Council and co-decision legislative procedures under what is now the ordinary legislative procedure. The full force of applying the EU's constitutional framework to 
a policy with the legislative procedure, the constitutional values expressed in the Treaties the Charter fundamental rights and the requirement of balancing econ policy corviurations with other policy objectives is then applicable.

In view of this transformation - from a market-oriented, ordoliberal-theory inspired $=$ onomic Constitution' to a fully fledged EU constitutional framework - tne question arises: what is today the 'economic' government and governance model of the EU constitutional structure and whether and if so, how, have they changed the legal and political understanding within the Union? ${ }^{12}$ Has the advent of the common currency and more fundamentally the outbreak of the crisis shifted the focus towards new models or concepts of European economic constitutionalism?

\subsection{THE PRE-CRISIS MICROECONOMIC AND THE MACROECONOMIC CONSTITUTION}

The idea of the creation of an internal market (which was referred to pre-SEA as a 'common' market) has always been inextricably linked with European economic integration through the objective of the removal of obstacles in the common market. ${ }^{13}$ The norms and policies that allow for the emergence of such a common, internal market were considered as the central plank of the EEC, ${ }^{14}$ the major 'vehicle' or instrument towards economic integration, ${ }^{15}$ and later, as an established part of the law of the European Union. ${ }^{16}$

12 Government will be used in the following to denote more classic 'constitutionalized' decision-making structures in which public actors such as the Commission, the European Parliament, the Council and national governments are central players. Governance is in the following considered as a more broad concept, encompassing the former but also taking into account public-private regulatory interaction, the use of incentives, soft law, information and other regulatory tools to influence reality. See e.g. Beate Kohler-Koch and Berthold Ritteberger, 'The Governance Turn in EU Studies' (2006) 44(Annual Review) Journal of Common Market Studies 27-49.

13 For a reading of the contextual background behind all major jurisprudential developments that led to the current state of the art see, Nicolas Bernard, 'On the Art of Not Mixing One's Drinks: Dassonville and Cassis de Dijon Revisited', in Miguel Poiares Maduro and Loic Azoulai (eds), The Past and Future of EU Law: The Classics of EU Law Revisited on the 50th Anniversary of the Rome Treaty (Hart Publishing 2010) 456, 456-457.

14 Grainne De Burca, 'Differentiation within the Core: The Case of the Common Market' in Grainne De Burca and Joanne Scott (eds), Constitutional Change in the EU (Hart Publishing 2000) 133.

15 See the Schuman Declaration 9 May 1950.

16 European Commission, Communication from the Commission to the European Parliament, the Council, the European Economic and Social Committee and the 


\subsubsection{Microeconomic Constitution}

The rules establishing a common market - both in the form of 'negative integration' by removal of barriers to trade and later also more in the form of 'positive integration' by EU-level re-regulation - were essentially based on what we refer to as microeconomic concepts: they dealt largely with single-market-related aspects such as the exercise of regulatory powers regarding markets and products, as well as with conditions of the movement of services and establishment.

However, while the founding EEC Treaty aimed at the removal of obstacles in the exercise of the economic freedoms and the construction of a free market economy, the completion of the internal market proved to be a more difficult process than had initially been believed. The 1985 Commission's White Paper stressed the need to adopt measures for the removal of physical, technical and fiscal barriers and for a new harmonization strategy. ${ }^{17}$ The introduction of a new Article 8A of the EEC Treaty under the Single European Act stipulated the progressive establishment of the internal market. The introduction of Article 100A EEC (now Article 114 TFEU) allowed for the adoption of measures aiming at removing obstacles in the internal market.

By means of legislative, regulatory and judicial law-making, the 'microeconomic' dimension of integration advanced. However, not least owing to the increasing and deepening interdependencies between the national economies on the basis of microeconomic rules, questions arose as to the necessity of complementing the microeconomic dimension of integration with a macroeconomic one..$^{18}$ Consequently, attention soon shifted to the necessary macroeconomic dimension of the EU's Economic Constitution for the economic integration project. The 1989 'Delors Report' noted the importance of a single currency that

would imply a common monetary policy and require a high degree of compatibility of economic policies and consistency in a number of other policy areas, particularly in the fiscal field. These policies should be geared to price stability, balanced

Committee of the Regions, 'A Single Market for $21^{\text {st }}$ Century Europe', COM(2007) 725 final, November 2007.

17 European Commission, Completing the Internal Market: White Paper from the Commission to the European Council (Milan, 28-29 June 1985) COM(85) 310, paras $61-65$.

18 This view was advocated by both the Report to the Council and the Commission on the realization by stages of economic and monetary union in the Community (The Werner Report), Luxembourg, 8 October 1970 and the Committee for the Study of Economic and Monetary Union ('J. Delors Committee'), 'Report on Monetary and Economic Union in the European Community' (17 April 1989). 
growth, converging standards of living, high employment and external equilibrium. Economic and monetary union would represent the final result of the process of progressive economic integration in Europe. ${ }^{19}$

\subsubsection{Macroeconomic Constitution}

The inclusion of more and more macroeconomic Constitution elements led to the debate on the Maastricht Treaty and raised issues of 'constitutionality' in various national bodies including, for example, the German Constitutional Court. ${ }^{20}$ Nonetheless, the Treaty of Maastricht entered into force and provided the EU with powers to achieve economic and monetary union, aiming at ensuring a more complete economic integration of the Member States. ${ }^{21}$ To this end, the new objective was complemented by economic and fiscal guarantees like the multilateral surveillance procedure, designed as a means of coordinating Member States' economic policies ${ }^{22}$ and the excessive deficit procedure, intended to ensure fiscal discipline. ${ }^{23}$ The extension of the economic objectives of the EU was hailed in some quarters as means of achieving a more full economic Union, an objective already listed in the initial Treaty of Rome. It, however, also generated some degree of unrest, especially among some economists and political scientists questioning the advantages and highlighting the

19 Committee for the Study of Economic and Monetary Union (presided by Jacques Delors), Report on Economic and Monetary Union in the European Community, 17 April 1989.

20 Bundesverfassungsgericht [German Federal Constitutional Court] 2 BvR 2134/92 and 2159/92, Brunner v. The European Union Treaty (1994) 57 CML Rev. 1 (1994), para 88. The main issue the Bundesverfassungsgericht was called to answer was whether the TEU violated Germany's core democratic principle by transferring too much power from the national to the supranational level and thus disempowering the national constitutional order against the EU. At the time, the German Constitutional Court placed particular emphasis on democratic legitimacy as a safeguard of national sovereignty. In the Court's view it was the democratic principle that set limits to the 'extension of the European Communities functions and powers, [therefore] functions and powers of substantial importance must remain with the German Bundestag'.

21 Besides the self-explanatory idea of the establishment an economic Union, see the preamble to the Treaty of Maastricht: 'Resolved to mark a new stage in the process of European integration undertaken with the establishment of the European Communities'.

22 See Articles 102a and 103 EC. Multilateral surveillance formally began in 1990 and was subsequently governed by Council Decision 90/141/EEC of 12 March 1990 on the attainment of progressive convergence of economic policies and performance during stage one of economic and monetary union, 24.3.1990 L78/3.

${ }_{23}$ Article 104c EC and the Protocol on the Excessive Deficit Procedure. 
disadvantages of a single currency union and doubting the viability of a monetary union without a fiscal union. ${ }^{24}$

The result was that the Maastricht Treaty implemented a monetary union, leaving, however, incomplete a possible economic policy union despite warnings that 'economic union and monetary union form two integral parts of a single whole and would therefore have to be implemented in parallel. ${ }^{25}$ While, thus, the common market and a common currency that make up the Monetary Union were established, no single fiscal policy controlled by a central authority existed. Such central authority had in early integration literature been seen as necessary component of full economic integration. ${ }^{26}$

Thus, upon the entry into force of the Maastricht Treaty the macroeconomic and the microeconomic elements coexisted on different levels of development. ${ }^{27}$ The microeconomic integration had been pursued since the early days of European integration through regulatory activity and supporting case law by the Court of Justice. ${ }^{28}$ In contrast, the macroeconomic requirements had been later added onto the treaties. Even the post-Maastricht tools such as the Stability and Growth Pact (SGP) and the Monetary Union provisions in the Treaties were rather 'dormant' provisions. Politically, a great reluctance to enforcement existed as the non-imposition of fines for non-compliance with

24 The 'no currency union without fiscal union' approach is based on the perception that the eurozone can only survive if the common currency is complemented by a fiscal union. In this respect see the theory of the Optimal Currency Area as developed by Mundell in Robert A. Mundell, 'A Theory of Optimum Currency Areas' (1961) 51 The American Economic Review 657. The theory of optimum currency area, as developed by Mundell, suggested two big issues to look at - labour mobility and fiscal integration. On both counts it was obvious that Europe fell far short of the US example, with limited labour mobility and virtually no fiscal integration. See also Jeffrey A. Frankel and Andrew K. Rose, 'The Endogeneity of the Optimum Currency Area Criteria' (1996) NBER Working Paper.

25 Committee for the Study of Economic and Monetary Union, Report on economic and monetary union in the European Community (Brussels 1989).

26 See for example Bela Balassa, The Theory of Economic Integration (Santa Barbara, CA, Greenwood Press 1961), see in particular 231-251. Therein Balassa discussed a centralized fiscal policy as a constituent of an economic union. Balassa did not consider a fiscal union, including a fiscal and tax union, as a constituent of the Economic Union. Instead, he considered that a common policy between states in very sensitive matters, like social security and income taxes, to be a component of later stages of a more fully developed integration.

27 Kaarlo Tuori and Klaus Tuori, The Eurozone Crisis - A Constitutional Analysis (CUP 2014) 37.

28 For a detailed account of this development see Brigitte Leucht, 'The policy origins of the European economic constitution' (2018) 24 ELJ 15. 
the rules of the SGP against France and Germany in the early 2000s show. ${ }^{29}$ This example demonstrates the leverage the Member States had as well as the reluctance of the EU institutions to make full use of the hard law elements (sanctions) of this 'construction'.$^{30}$ If one regards such non-enforcement of the rules as indication of failures of the Treaty of Maastricht's macroeconomic elements, one of the reasons for this might be that in its main policy elements in 'the progress and the course of the integration process were not subjected to political debate or deliberation'. ${ }^{31}$ Their application relied on a largely intergovernmental process and cooperation.

It was the Lisbon Treaty that, by expanding the objectives of the Union and the values it was premised upon, marked a renewed attempt to tackle the growing democratic deficit of the EU's micro- and macroeconomic constitution. Some of the Lisbon Treaty's main contributions in this sense consisted of empowering the role of the EP through extending the co-decision procedure to almost all policy areas as well as giving legally binding status to the Charter of Fundamental rights. Not least owing to the social rights in the Charter, the Lisbon Treaty was seen as an attempt to address the persisting 'social deficit' of European integration which had focussed very much on individual economic rights more than on collective social security systems..$^{32}$ One of the decisive innovations of this new step of 'constitutionalization' of the Union's legal basis is that elements of the Union's macroeconomic constitution could

29 2546th Meeting of the Council of the European Union (Economic and Financial Affairs), Brussels, 25 November 2003 and the press of the time, 'Deficit and Defiance', The Economist, 2 September 2003 https:/www.economist.com/node/2031381 (accessed 30 December 2018) and 'France and Germany evade deficit fines' (2003) The Guardian, 25 November 2003 https:/www.theguardian.com/business/2003/nov/ 25/theeuro.politics (accessed 30 December 2018).

30 See for instance the (in)famous Case C-27/04 Commission v. Council [2004] ECR I-6649, which was initiated by the fact that the ECOFIN Council found that Germany and France had incurred excessive budgetary deficits, yet, it decided not to impose any sanctions but only issue recommendations. The Commission brought the case before the CJEU which decided that the Council did not have the right to make such recommendations to initiate the EDP, a prerogative strictly reserved to the Commission. This case was not the only one: indicatively, over the first 10 years of monetary union, the Excessive Deficit Procedure was triggered 15 times, including seven cases of Eurozone members, which, under the telos and the letter of the law would have led to sanctions. Nevertheless, no sanctions were ever imposed.

31 Christian Joerges, 'A Renaissance of the European Economic Constitution?' in Ulla Neergaard, Ruth Nielsen and Lynn M. Roseberry (eds) Integrating Welfare Functions into EU Law - From Rome to Lisbon (Djoef 2009) 37, 46.

32 See with further discussion e.g. Christian Joerges, Florian Rödel, 'Informal Politics, Formalized Law and the "Social Deficit" of European Integration: Reflections after the Judgments of the ECJ in Viking and Laval' (2009) 15 ELJ 1. 
no longer be examined in isolation from their broader concept of the social elements anc fundamental rights dimension. Elements of the macroeconomic Union couiu now no longer be treated as a sector-specific intergovernmental cooperation in isolatior EU objectives and values such as fundamental rights and EU cohesion policy. Along the 'upgrade' of fundamental rights in the European (economic) Constitution, the change in the position of competition policy in the Treaty ${ }^{33}$ was counterbalanced by the elevation of the establishment of the internal market and of the EMU An Union objectives in Article 3 (3) and (4) of the TEU, these aims previously being viewed as merely instrumental. $^{34}$

\subsection{CRISIS-INDUCED CHANGES TO THE EUROPEAN ECONOMIC CONSTITUTION}

In the turmoil of the financial crisis the economic constitutional framework of the EU was profoundly challenged. The crisis, while it started as a financial and sovereign debt crisis, soon also became a political crisis questioning the legitimacy of the Lisbon Treaty's institutional setup and democratic accountability. ${ }^{35}$

\subsubsection{Microeconomic Constitution}

An initial reaction to the crisis was to resort to the classic microeconomic approach. The way to control the banking crisis was to assess national support for private undertakings by means of EU State aid rules. As no risk management mechanism existed at the time, the Commission applied looser criteria when assessing requests to grant aid in order to avoid a total failure of the banking sector. Resorting to state aid rules to save the 'too big to fail' banks demonstrated the need for reform of the financial regulatory framework both within and outside the EU. Therefore, at a later stage, legislation

33 The protection and guarantee of undistorted competition, as until recently entrenched in the EC Treaty, under Article $3(\mathrm{~g})$, was omitted from the catalogue of the aims and objectives of the European Union subsequent to French pressures for a more social than capitalistic model. However, the protection of undistorted competition remains an aim of the EU as it was included in the 'Protocol on the internal market and competition'.

34 Erika Szyszczak, 'Building a Socio-economic Constitution - A Fantastic Object?' (2011-2012) 35 Fordham Int'1 L.J. 1364, 1386.

35 On the multidimensionality of the crisis see Damian Chalmers, Marc Jachtenfuchs and Christian Joerges, 'The Retransformation of Europe' in Damian Chalmers, Marc Jachtenfuchs and Christian Joerges (eds), The End of the Eurocrats' Dream - Adjusting to European Diversity (CUP 2016) 1, 1-3. 
ped ised designed to strengthen the Eurozone's banking system and ensure that systemic banks would no longer be considered as 'too big to fail' but would instead be allowed to enter resolution or liquidation without threatening financial stability. This was the genesis of the European Banking Union.

Ba 1 king Union should, in principle, consist of three pillars: ${ }^{36}$ single supervisivil, ${ }^{-7}$ single resolution ${ }^{38}$ and common deposit insurance. However, the latter is yet to be put in place. ${ }^{39}$ The European Central Bank (ECB) under the auspices of the Single Supervisory Mechanism (SSM) supervises the most 'significant' banks in the Eurozone in order to avoid bank failures that could have a cross-border effect. Once a bank is approaching insolvency then the Single Resolution Mechanism kicks in. The Single Resolution Board (SRB) at the EU level together with the national resolution authorities are empowered to resolve banks according to certain rules and criteria provided by the EU legislature. The ultimate goal is to preserve the critical functions of failing banks and to minimize the cost for taxpayers. In this process, the SRB can use EU funds, the Single Resolution Fund (SRF), which aims at covering all resolution-related expenses. ${ }^{40}$ Ideally, the SRF should be backed by a fiscal backstop, such as the ESM; however the existing arrangements are de facto inapplicable. ${ }^{41}$ The third pillar, the European Deposit Insurance Scheme (EDIS), which would ensure common protection to insured depositors by compensating them in case of resolution, is still missing. EDIS, when enacted, would be administered by the $\mathrm{SRB}$, as is the case with the SRF. However, whilst the SRF is designed to facilitate resolution and its funds should, in principle, be redeemed once the ailing bank has gone successfully through resolution, EDIS has a pure loss-absorbing character; insured depositors in one Member State should be reimbursed with the use of EU funds once the national deposit insurance funds are fully used.

Considering this new regulatory architecture, a series of new challenges emerged as regards the new bodies' governance, competence and accountability, and whilst the ECB has been criticized, mostly on grounds of accountabil-

36 With respect to Banking Union and the role of the ECB in the crisis see in particular, Chapters 2 (Adamski), 3 (Tuori), 11 (Gren) and 12 (Asimakopoulos) in this book.

37 Regulation (EU) No. 1024/2013 of 15 October 2013 (SSMR).

38 Regulation (EU) No. 806/2014 of 15 July 2014 (SRMR).

39 David Howarth and Lucia Quaglia, 'The Difficult Construction of a European Deposit Insurance Scheme: A Step too Far in Banking Union?' (2017) Journal of Economic Policy Reform 1.

40 Articles 1 and 67-78, SRMR.

41 Ioannis G. Asimakopoulos, 'International Law as a Negotiation Tool in Banking Union; The Case of the Single Resolution Fund' (2018) 21 Journal of Economic Policy Reform 118. 
ity, ${ }^{42}$ the establishment of the SRB seems to have truly pushed the boundaries of the European Economic Constitution. The SRB constitutes an EU agency established on the basis of Article 114 TFEU and empowered to such an extent that it can define resolution policies at a national level, and directly circumvent national authorities when it takes measures that limit fundamental rights, such as the right to property and the freedom to contract. In the meantime, the loss-sharing component of the Banking Union, as reflected in the absence of a fiscal backstop to the SRF and of EDIS, illustrates the barriers that still lie ahead towards the establishment of a fully fledged Banking Union.

\subsubsection{Macroeconomic Constitution}

The economic and political upheaval of the crisis served to highlight the consequences of the lack of constitutional embedding of the Economic Union with highly integrated states. Many questions arose for the first time since the introduction of the Euro as a common currency. Could an entire state be supported in case of danger of cessation of payments in the context of defaulting on loans and other payments?

While rules addressing 'bail-outs' for private companies existed in the form of State aid provisions, although they were not always respected, Member States were subject to other, less clear, rules which did not in themselves entirely answer whether, and how, a potential bailout could and should be effectuated under EU Law. Was there a legal (and legitimate), but least invasive, way to enhance and enforce the (existing) SGP in order to avoid further defaults and to pave the way for more fiscal cooperation? The main concern of the EU was to find ways to deal with this emergency situation and set up a new (ideally sustainable) EU 'crisis-management' economic governance. As the existing EU economic constitution was faced, then, with several government and governance challenges, the new framework was created mostly ad-hoc in reaction to these problems for which there was no pre-existing constitutional template.

One of the main sources of problems can be traced to the only partial legal integration of the economic (and fiscal) policies of the Member States, as opposed to the total monetary integration for the Eurozone members. The fiscal and economic policy decisions, however, had effect beyond the borders of the Member States in that the consequences of rising interest rates or employment

42 Deirdre Curtin, "'Accountable Independence" of the European Central Bank: Seeing the Logics of Transparency' (2017) 23 ELJ 28; Argyro Karagianni and Miroslava Scholten, 'Accountability Gaps in the Single Supervisory Mechanism SSM Framework' (2018) 34 Utrecht J Int'l \& Eur L 185. 
policies could take effect beyond the borders and outside the deciding constituencies. The lack of political steering capacities at EU level that would serve to work towards a convergence of the Member States' economic and social development in the long term was identified as one of the key problems. ${ }^{43}$

Among the exigencies the EU had to deal with were Treaty impediments to joint forms of action; institutional design (within and outside of the Treaty framework) for actors assigned to underta ; macroeconomic policy design; democratic legitimization of decision-makmis; and (re-)balancing of the division of powers between the Member States and the Union-level.

With regard to the institutional design, at the dawn of the crisis, attempts were made to remedy the three major problems of the institutional structure of the Lisbon Treaty's approach: the 'no bail out', the 'no efficient fiscal supervision' and the 'no enforcement of sanctions' against Member States violating the obligations under the SGP were part of ambitious plans for the reform of I ropean Economic Constitution. These efforts materialized progressively umough hard and soft law provisions and tools outside the traditional EU law framework. The Six Pack, the Two Pack and the Fiscal Compact aimed at enhancing fiscal supervision and facilitating the imposition of sanctions while the European Semester's goal was to advance dialogue between Member States and the Commission as to the formers' budgetary policies. At the same time, shock absorption mechanisms were deemed necessary and took the form of new institutional structures such as the $\mathrm{ESM},{ }^{44}$ the $\mathrm{EFSM}^{45}$ and the EFSF. ${ }^{46}$ For some of these, an amendment of the TFEU was necessary ${ }^{47}$ and new institutional arrangements had to be invented to override the existing constitutional barriers. In the meantime, institutions with no previous law-making powers, such as the Eurogroup, were becoming empowered and allowed to

43 Jürgen Habermas, The Crisis of the European Union - A Response (English edition) (Polity Press 2012) 50.

44 The European Stability Mechanism (ESM) is the permanent crisis resolution mechanism for the countries of the euro area. The intergovernmental treaty establishing the ESM was adopted on 2 February 2012.

45 The European Financial Stabilization Mechanism (EFSM), legally based in Article 122 (2) TFEU, is a programme whose purpose is to provide loans to EU Member States in financial difficulty.

46 The European Financial Stability Facility (EFSF), is a special purpose vehicle, outside the EU Law framework, established as a private company under Luxembourg law with the Member States as shareholders.

47 The necessity of this Treaty amendment was strongly opposed, see for instance, Bruno De Witte, 'The European Treaty Amendment for the Creation of a Financial Stability Mechanism, in European Policy Analysis’ (2011) SIEPS Paper, p. 5. 
decide on the most important issues regarding fiscal and economic policies, ${ }^{48}$ while the ECB through its unconventional monetary policy measures, often acted as a lender of last resort. ${ }^{49}$ Being simultaneously a member of the troika, it was eften accused of violating Treaty provisions and compromising its independence. ${ }^{50}$

These shock absorption mechanisms, namely the ESM and the ECB's unconventional monetary policy measures, were subject to constitutional challenges on a number of grounds. ${ }^{51}$ Those grounds had to do both with the encroachment of the Member States' powers, even their constitutional identity, ${ }^{52}$ as well as the expansion of the Union's competences and, as suggested, the outright violation of the market-based Treaty provisions. ${ }^{53}$

From the perspective of the history of European integration it might not come as a surprise that in the initial response to these questions the EU relied to a large extent on the intergovernmental method - despite the difficulties associated with this method in terms of speed of decision-making owing to the requirements of unanimity. By necessity and/or by design, EU law resulted in integration of the executive branches of powers through structures of cooperation between governments and executive bodies of the Member States and the EU on the basis of public international law, private law and some EU law.

48 See Uwe Puetter and Sergio Fabbrini 'Integration without Supranationalisation: Studying the Lead Roles of the European Council and the Council in Post-Lisbon EU politics' (2016) 38 Journal of European Integration 5, 481.

49 Daniel Wilsher, 'Law and the Financial Crisis: Searching for Europe's New Gold Standard' (2014) 20 European Law Journal 241; Klaus Tuori, 'Has Euro Area Monetary Policy Become Redistribution by Monetary Means? 'Unconventional'Monetary Policy as a Hidden Transfer Mechanism' (2016) 22 ELJ 838, 856.

50 See Opinion of Advocate General Cruz Villalón in Gauweiler and European Parliament, European Parliament Resolution of 17 April 2013 on 2011 Annual Report of the European Central Bank, 2012/2304(INI), April 2013, http://www.europarl .europa.eu/sides/getDoc.do?type=TA\&reference=P7-TA-2013 0176\&language=EN . Note that the role and the degree of the involvement of each of the EU institutions in the contemplation of the country specific programmes was the subject of the Ledra and Mallis cases.

51 Case C-370/12 Pringle EU:C:2012:756 [2012]; Case C-62/14 Gauweiler and Others EU:C:2015:400 [2015]; Case C-493/17 Weiss and Others EU:C:2018:1000 [2018].

52 Bundesverfassungsgericht [German Federal Constitutional Court] 2 BvR 2728/13 [2014]. The concept of the 'constitutional identity' in German law is a complex one. A very detailed account of it is provided in Monica Claes and Jan-Herman Reestman, 'The Protection of National Constitutional Identity and the Limits of European Integration at the Occasion of the Gauweiler Case' (2015) 16 German Law Journal 4 $917,921$.

53 Namely, Article 123 TFEU, the prohibition of monetizing debt and Article 125 TFEU, the 'no bail-out' clause. 
The subsequent 'constitutionalization' of these matters, i.e. their integration into the general constitutional framework of the EU, is a process which is ongoing. This includes questions of compliance of these macroeconomic policy elements with the principles of transparency and democracy as well as their compliance with fundamental constitutional values and fundamental rights.

Similarly, the entire legality of the ESM was based on the unclear distinction between monetary and economic policy, an underlying theme in many of the high-profile CJEU cases in the area such as Pringle, Gauweiler and Weiss and Others. ${ }^{54}$ Gauweiler and Weiss and Others, in essence, question whether the essential limitation of ECB monetary policies regarding the economic policy decisions has been complied with. Competences of the ECB are strictly circumscribed by the prohibition of monetary financing of Member State debt by means of direct purchases as opposed to open market operations of the ECB involving Member State bonds (Article 123(1) TFEU). The question raised in both cases is whether the intended or unintended side-effects of a measure adopted by the ECB as a monetary policy instrument could lead to the fact that they are ultra vires regarding economic policy prerogatives of the Member States. Vague notions such as that of price stability are established by the Treaties as another 'cornerstone' of the 'new' European economic Constitution (Article 119(2) TFEU). ${ }^{55}$ While price stability has been defined by the ECB Governing Council as maintaining inflation rates below, but close to, $2 \%$ over the medium term, ${ }^{56}$ the ECB has often considered 'financial stability' as an ancillary goal falling within monetary policy, possibly in an effort to 'clear' the ECB's unconventional measures, at least from a mandate perspective..$^{57}$ Naturally, financial stability - a term much more vague than the quantifiable price stability - is relevant for maintaining price stability. The question that arises, however, is whether the ECB has a merely coordinative role in maintaining financial stability.

54 See the Pringle-Gauweiler-Weiss case law (n. 51 above).

55 Article 119(2) TFEU the EMU activities shall include "the definition and conduct of a single monetary policy and exchange-rate policy the primary objective of both of which shall be to maintain price stability and, without prejudice to this objective, to support the general economic policies in the Union, in accordance with the principle of an open market economy with free competition'.

56 See the definition of price stability provided by the European Central Bank https://www.ecb.europa.eu/mopo/strategy/pricestab/html/index.en.html (accessed 30 December 2018).

57 The primacy of monetary policy has also been recognized by the ECB, see Yves Mersch, 'Financial Stability and the ECB', 6 September 2018, https://www.ecb.europa .eu/press/key/date/2018/html/ecb.sp180906.en.html (accessed 30 December 2018). 
Other notions of constitutionality were also challenged via the creative use of existing forms of act. The pre-ESM 'emergency' response to the crisis, was for example heavily premised on private law, notably Memoranda of Understanding (MoU), which often contained strict conditions to be fulfilled by the recipient states for the funding to be released. This 'conditionality' was spelled out by way of adjustment programmes to which the recipient countries committed themselves as a condition for the disbursement of the loans. ${ }^{58}$ The role and the degree of the involvement of each of the EU institutions in the contemplation of the country-specific programmes was the subject of the Ledra and Mallis cases. ${ }^{59}$ The questions in these cases concerned, inter alia, whether the Commission had lived up to the challenge of ensuring that the $\mathrm{MoU}$ were consistent with EU law and fundamental rights.

Another example of the use of forms of private law for achieving macroeconomic goals was the establishment of the European Financial Stability Facility as a private company under Luxembourg law with the Member States as shareholders. This structure functioned as a temporary crisis resolution mechanism by issuing bonds and other debt instruments on capital markets, in order to provide financial assistance to Greece, Ireland and Spain. In German language a specific term has been developed for this kind of use of private law arrangement between states for achieving public goals: Völkerprivatrecht - which might translate as 'intergovernmental private law' or 'public international private law'.

These forms of act had been established in parallel with the European Financial Stabilization Mechanism, a structure under public law of the Union, which enabled the Commission to borrow in the financial market up to a total of $€ 60$ billion on behalf of the Union and then to lend the proceeds to the Member States in need.

The challenges in what we referred to here as the macroeconomic economic constitution have, thus, proven to be multidimensional. They include the use of different tools from private law, intergovernmental private law, public international law and EU law to grant the EU more competences. In part these competences have been transferred to highly specialized agencies such as the ECB with no direct democratic mandate. The resulting concentration of powers in the hands of various emanations of the executive branches of powers

58 For the role of conditionality in the disbursement of EU funds and its relationship to the Country Specific Recommendations, see Chapter 12 (Asimakopoulos) in this book.

59 Joined Cases C-8/15 P to C-10/15 P Ledra $v$ Commission and European Central Bank EU:C:2016:701 [2016]; Joined Cases C-105/15 P bis C-109/15 P Mallis and Others $v$ Commission and ECB EU:C:2016:702 [2016]. See on this the analysis developed in Chapter 8 (Zaccaroni). 
has proven quite challenging for constitutional notions such as the idea of separation of powers ('the institutional balance in the EU'). The CJEU, in the interest of economic stability has in the immediate time of crisis shown great flexibility in the interpretations of Treaty provisions, ${ }^{60}$ but that leniency has already started to give way to stronger requirements of procedural justification in cases such as Weiss and Others. ${ }^{61}$

\subsection{CONSTITUTIONALISATION OF THE ECONOMIC CONSTITUTION(S)?}

The EU Economic Constitution is in the process of continuous transformation. The term itself is quite controversial. De Witte for example has referred to the changes that took place during the crisis period post-Lisbon as "interstitial changes'. With this term he refers to informal constitutional changes through institutional practice that can complement the existing Treaty rules, in which case no transformation has occurred, or transform them. ${ }^{62}$ Weiler had similarly argued earlier that constitutional change/transformation could ensue without any formal amendment as long as the Member States accepted those changes. ${ }^{63}$ The CJEU case law allowing institutional practice as legal basis for extraconstitutional practices is, however, thin. ${ }^{64}$ Therefore, the question of the definition of what is meant by the notion of 'transformation' is crucial, in particular in the crisis context, as one of the most common criticisms in academia echoes the unconstitutionality and illegality of those changes. Had those 'changes' instead been classified as merely interpretations of or 'complements' to the economic constitution, disapproval would probably be minimal.

Tracing the development from a microeconomic regulatory approach towards an ever more macroeconomic coordination and intervention-based approach, the crisis has been catalytic for these developments accelerating legal integration, sometimes against the will of its constituents. ${ }^{65}$ Although

\footnotetext{
60 See e.g. its approach in Pringle (n. 51 above).

61 Case C-493/17 Weiss and Others EU:C:2018:1000 [2018].

62 Bruno De Witte, 'Euro Crisis Responses and the EU Legal Order: Increased Institutional Variation or Constitutional Mutation?' (2015) 11 EU Const 434, 436.

63 Joseph H. H. Weiler, 'The Transformation of Europe' (1991) 100 The Yale Law Journal 8 2403, 2438.

64 To our knowledge, Köster is one of the rare examples for this approach. See Judgement of 17 December 1970 in case 25/70 Köster.

${ }^{65}$ As Scharpf puts it, the economic and social costs of economic over-integration have been particularly high, especially for the financially assisted countries. Franz W. Scharpf, 'The Costs of Non-disintegration: The case of the European Monetary Union' in Damian Chalmers, Marc Jachtenfuchs and Christian Joerges (eds), The End of the Eurocrats' Dream - Adjusting to European Diversity (CUP 2016) 29, 45.
} 
transformation is a necessity as different or new problems require different and new instruments and techniques to tackle them, the fundamental constitutional values of the Union should provide guidance and establish the framework for the structure of the economic constitution. Since the crisis-induced transformation of the EU's economic constitution is far from finalized, we would like to point to some of the structural and substantive requirements for future developments.

The various crises of the decade since the entry into force of the Treaty of Lisbon have highlighted the deficiencies of the 'early macroeconomic Constitution'. Subsequently, the EU was forced to find structures and procedures of economic government and governance to cope with them. One of the institutional and constitutional imperfections that contributed to the crisis was, arguably, the lack of an effective mechanism at the Union level to hold Member States accountable for fiscal profligacy. This was partly a democratic problem or, as described by some, a tension between the 'liberal' and the 'democratic state'. Although this distinction is ill adapted to the-both the concepts of democracy and liberalism, it has gained traction. In the context of this argument, the liberal state - as enforcer of market discipline - had succumbed to the democratic state, which did not wish to implement any fiscal consolidation measures in order for the national governments to be re-elected. ${ }^{66}$ The idea behind the new long-term crisis preventative measures was that, although the gist of the pre-crisis policy was right, a strengthening and more efficient enforcement of it based on a stronger technocratic oversight of national economic management was needed. This was the underlying idea behind the new economic governance measures, namely the Six Pack, the Two Pack and the European Semester, ${ }^{67}$ which provided for a continuous monitoring of the Member States' budgets and an increased possibility of the imposition of sanctions in case of no compliance; through the insertion of the reverse qualified majority in the decision-making process. ${ }^{68}$ This has led to several contentious debates between and within the Commission, the Council and the affected Member States, not only as to the potential of imposing (counter-productive?) sanctions but also as to how far ean the Commission with regard to budgetary surveillance and imposing budgetary amen.....nts. Could this involvement, suggesting changes in the context of the European Semester to fiscal policy and other strietly reserved - until recently - national policy areas amount to an encroachment of a Member State's constitutional identity, as this

66 Huw Macartney, 'The Paradox of Integration? European Democracy and the Debt Crisis' (2014) Cambridge Review of International Affairs, 12.

67 These measures are presented in more detail in Chapters 4 (Allemand) and 10 (Pantazatou and Asimakopoulos) of this volume.

68 Regulation No. 1173/2011, Recital 7. 
was argued by Germany in the context of the ea $e{ }^{69}$ Despite the strengthening of the economic governance through more rigurous enforcement, no sanctions have been imposed so far, in spite of the finding of excessive economic imbalances in several countries by the European Commission. ${ }^{70}$ This car $\mathrm{d}$ in two possible ways: first, in the question of enforcement, political inter ruions and bargaining can still interfere with the activation of sanctions, leading to 'stronger' and 'weaker' Member States within the Eurozone; second, as officials from the European Commission suggest, no sanctions were needed for the new economic governance procedures to have an impact. ${ }^{71}$

In the bid for new 'governance techniques' the EU was compelled to supplement its toolbox with novel instruments that were not used before. It resorted to public international law instruments (such as the Fiscal Compact) and intergovernmental private law instruments (ESM, MoU). Arguably, thereby it was possible to circumvent EU procedural rules allowing for national vetoes and in part also EU constitutional principles. Yet again, one could convincingly argue that budgetary independence and autonomy of the Member States were never really enshrined in the Treaties. Adjustment programmes premised on MoU laid out very specific lists of measures to be fulfilled by the recipient Member States, including measures pertaining to direct taxation and social policy. ${ }^{72}$ Furthermore, the constitutionality of the ESM and its compliance with the 'no bail-out' clause, although it has been 'cleared' by the CJEU, ${ }^{73}$ has been contested in literature. ${ }^{74}$

69 Bundesverfassungsgericht [BVerfG] [Federal Constitutional Court], Jan. 14, 2014, 2 BvR 2728/13, https://www.bundesverfassungsgericht.de/SharedDocs/ Entscheidungen/DE/2014/01/rs20140114_2bvr272813.html, para. 5.

70 See Communication from the Commission, '2017 European Semester: Assessment of Progress on Structural Reforms, Prevention and Correction of Macroeconomic Imbalances, and Results of In-depth Reviews under Regulation (EU) No. 1176/2011' COM(2017) 90 final.

71 Jean Charles Bricongne and Alessandro Turrini, 'The EU Macroeconomic Imbalance Procedure: Some Impact and no Sanctions' (2017) Vox, 22 June 2017, https://voxeu.org/article/eu-macroeconomic-imbalance-procedure-some-impact-and -no-sanctions (accessed 30 December 2018).

72 See Section 3.2.1.

73 Judgment of 27 November 2012, Pringle, C-370/12, EU:C:2012:756.

74 See for instance, Matthias Ruffert, 'The European Debt Crisis and European Union Law' (2011) 48 CML Rev. 1777, 1785; Rainer Palmstorfer, 'To Bail Out or Not to Bail Out? The Current Framework of Financial Assistance for Euro Area Member States Measured Against the Requirements of EU Primary Law' (2012) 37 EL Rev. 771; Jean-Victor Louis, 'The No-bailout Clause and Rescue Packages' (2010) 47 CML Rev. 971, 977; Jörn Pipkorn, 'Legal Arrangements in the Treaty of Maastricht for the Effectiveness of the Economic and Monetary Union' (1994) 31 CML Rev. 275; 
While the new design was largely premised on voluntary policy coordination and participation in international treaties, highlighting thus the intergovernmental character of the new economic Constitution, democratically deliberative decision-making and judicial accountability are far less evolved in the macroeconomic constitution of the EU in its current form. This 'democracy oversight' in the development of the EMU ${ }^{75}$ raises persistently fundamental constitutional questions for the Union pertaining to issues of legality, (social and democratic) legitimacy and compliance with the rule of law principles.

Whilst the recently arisen-ad-hoc 'crisis measures'-are deeply technical, requiring sophisticated mastery of detail by expert regulators, they are further highly political. The conditionalities attached to any (pre- or post- ESM) financial assistance, as well as the Country Specific Recommendations made by the Commission to the Member States, have direct and immediate implications for the economic and social future of Europe and its Member States, pertaining for instance to employment, social security and taxation issues. As such they require 'higher' democratic legitimacy, and in order for them to be achieved the design of decision-making procedures in the EMU and the regulation of the financial markets need to ensure that the views and interests of those affected by ae isions can potentially influence the policy choices made. At the same tinic, despite the high degree of economic integration achieved so far, in view of the tremendous economic differences among the Member States, there are questions whether (potential) solutions and policy approaches must be adapted to the variable geometry of the participating EU members and the differences in their economic conditions.

However, one finding of the review of the constitutional transformations of the macroeconomic constitution is that the EU in practice has resulted in empowering 'executive' branches of powers. They have strengthened institutions created on the European and international level, and have given rise to intergovernmental cooperation empowering national governments. In reality, a consequence has been the empowerment of the EU Council and the (indirect) upgrade of the Eurogroup and the Troika (and by implication the IMF) in the EU Economic Constitution. This rebalancing of powers away from national parliaments' budget rights and decision-making about economic policies best suited for their countries towards a small group of highly specialized technocratic experts has limited the sovereignty of the Member States - in particular,

Heather Hofmeister 'To Bail Out or Not to Bail Out?-Legal Aspects of the Greek Crisis' (2011) 13 Cambridge Yearbook of European Legal Studies 113.

75 In the sense that voters (EU citizens) were not asked (in most cases where national referenda did not take place) whether they wanted the Maastricht Treaty, or the SGP or the EMU. 
those under financial aid, predicating the passage from market discipline to bureaucratic discipline. ${ }^{76}$

Institutionally, within the EU, the consequences are also felt. A focus on the definition for conditions for financially assisted states shows that the (vertical) transfer from the national to the supranational that incorporated inter alia fiscal, tax, employment and social policy-making powers has rendered the European Counci $\underline{\underline{a}}$ lecision-maker with budgetary implications for the Member States. The rusur, in terms of institutional balance, is a more political administration in the Union consisting of the European Council setting the main policy orientations; the Council coordinating EU economic policy mostly within the ECOFIN and Eurogroup constellations and their 'Euro summit' informal meetings have become increasingly institutionalized based on political statements. ${ }^{77}$ The role of the Commission has been reinforced in that it now plays a central role in monitoring implementation, and thus disciplining Member States and making detailed proposals for measures in EMU matters, while the ECB has been promoted to a key player with its role in monetary policy and the Systemic Risk Board and the ESAs supervising the financial markets. The executive branch of powers now takes eminently political decisions - for example the design of the rescue plans taken in the 'Eurogroup informal' meetings under political bargaining. ${ }^{78}$

However, one might, in line with Habermas, observe that a threshold has been passed. ${ }^{79}$ While in the context of the original microeconomic Constitution, problems of distributive justice were not meant to be tackled by the relevant internal market or competition law provisions (although Article 106 and 107 TFEU certainly do have such implications), such problems became more visible especially in the post-crisis macroeconomic Constitution framework. ${ }^{80}$ The requirement for a deliberative, political debate about economic policies has

76 Michael Ioannidis, 'Europe's New Transformations: How the EU Economic Constitution Changed during the Eurozone crisis' (2016) 53 CML Rev. 1237, 1281.

77 Christian Calliess, 'From Fiscal Compact to Fiscal Union? New Rules for the Eurozone' (2012) 14 Cambridge Yearbook of European Legal Studies, 114-115.

78 See also Joseph H. H. Weiler, 'The Legitimacy Credit Crunch of the European Union' (2012) Keynote Speech at the Opening of the XXV FIDE Congress.

79 Jürgen Habermas, 'Europe's Post-democratic Era - The Monopolisation of the EU by Political Elites Risks Reducing a Sense of Civic Solidarity That's Crucial to the European Project', (2011) The Guardian, 11 November 2011, https://www.theguardian .com/commentisfree/2011/nov/10/jurgen-habermas-europe-post-democratic (accessed 30 December 2018).

80 One cannot ignore the existing similar repercussions, albeit to a lesser extent, on the microeconomic Constitution whereby the resolution of banks and all the associated risk-sharing issues is entrusted to an EU agency, the Single Resolution Board. On this points see the analysis made in Chapter 12 (Asimakopoulos). 
risen on the EU level with an increasing involvement of EU decision-making in redistributive policies for example through involvement in budgetary policy, tax and spending decisions in the Meliuvi States. These issues have not been adequately addressed in the current macroeconomic constitutional framework established ad-hoc over the past years. Conditions have to be created that would allow the transfer back of these issues from a technocratic 'expert'-driven approach in the Council towards a more political, deliberative discourse about the best way forward and for a self-correcting political process of public debate-in place. ${ }^{81}$

The tradition of functional integration theories conceived of the EU as the equivalent to a 'regulatory state', mainly understood aims as correcting market failures in an allegedly non-interventionist construction. ${ }^{82}$ The EU, however, in the past years is moving towards a different model. Maybe as a result of the crisis, powers with regard to both the macro- and the microeconomic powers have been continuously growing. This has resulted in greater redistributive decisions taken the European level, without, however, a stronger political debate and politicized legitimization of Union policies. ${ }^{83}$ In this respect, Habermas has rightly criticized that the increasing empowerment of the Council risks replacing 'the executive federalism implied in the Lisbon Treaty with an intergovernmental domination of the European Council [...] a regime that would allow for the projection of market imperatives onto national budgets without any specific democratic legitimation' ${ }^{84}$ At the same time, economic decision-making by Member States in the wake of economic integration has effects beyond its borders. Yet with the mease in the macroeconomic constitution, decision-making options on thu national level have been hollowed out, further amplifying wing democratic deficit of decision-making at the national level.

$81 \quad$ See Habermas (n. 79 above).

82 Giandomenico Majone, 'Regulating Europe: Problems and Perspectives' (1989) Jahrbuch zur Staats - und Verwaltungswissenschaft 3159.

83 Sergio Fabbrini, 'After the Euro Crisis: The President of Europe, A New Paradigm for Increasing Legitimacy and Effectiveness in the EU' (2012) CEPS Paper No. 12, 2.

84 Jürgen Habermas, 'Democracy is at Stake' (2011) Le Monde, 27 October 2011, https://voxeurop.eu/en/content/article/1106741-juergen-habermas-democracy-stake (accessed 30 December 2018). 